\title{
PROLONGED DURATION OF APNOEA DUE TO SUCCINYLCHOLINE
}

\author{
P. M. F. MCGARRY, M E., B CH, D.A. (IRELAND), D A. (ENG.) *
}

IN 1949 Bovet and his colleagues (1) described the paralysing action of the bis-choline esters of succinic acid, showing that they produced rapid paralysis of short duration Concurrently Bovet-Nitti (2) showed that the destruction of these compounds in the blood was due to enzymatic hydrolysis. Evans, Gray, Lehmann and Silk (3) further demonstrated that the pseudo-cholnesterase of the serum was chrefly responsible for the hydrolysis, the true cholinesterase of the cells having little effect.

The stages in the breakdown are first, hydrolysis at a fairly rapıd rate to succinylcholine and choline, and then hydrolysis of succinylmoncholine more slowly to succinic acid and choline, less than 3 per cent being excreted unchanged in the urine (4) This breakdown usually occurs in three to five minutes, but numerous case reports of prolonged duration have appeared in the literature (5-11).

Scoline ${ }^{\circledR}$ (succinylcholme chlonde dihydrate) was the brand used in the following two instances of prolonged apnoea.

Case 1

H B A 70-year-old woman was admitted with large bowel obstruction. When presented for operation she was adequately hydrated, her B P was 120/80 and she was in a reasonably fit condition

Morphia gr 1/6 and atropine gr $1 / 100$ were given one hour before operation

Induction was with Thiopentone $250 \mathrm{mg}$ and Scolne $50 \mathrm{mg}$ A No. 8 Magill's cuffed catheter was passed and respirations recommenced in four minutes. Mantenance was with 6 litres nitrous oxide and 2 hitres oxygen An intravenous infusion of Scoline 0.1 per cent was commenced (12).

The total operatıng time was two hours, during which a short circuit anastomosis was performed for carcinoma of the colon Secondaries were present in the liver $U p$ to the time of commencement of closure of the peritoneum, periods of spontaneous respirations were permitted and adequately assisted where necessary In all $500 \mathrm{mg}$ of Scoline ${ }^{3}$ were used As relaxation for closure of the peritoneum was madequate, $50 \mathrm{mg}$ of Scoline were given from a syringe. The operation was completed twenty minutes later, but apnoea still persisted There were, however, very tny movements of the rebreathing bag.

Nikethamide $10 \mathrm{cc}$ was given without effect, in fact the faint movements of the rebreathing bag disappeared.

Controlled respuration was carried out using 100 per cent oxygen for periods up to ten minutes, and both hypo- and hyperventilation were tred without success

Respirations gradually began to return $1 \frac{3}{4}$ hours from the time when the last dose of Scoline ${ }^{\circledR}$ had been administered, but it was three-quarters of an hour

'Children's Hospital, Winnipeg, Man Formerly Anaesthetıst, Bromley Group Hospitals, Kent, Eng 
later before tidal exchange was adequate. Consciousness began to return shortly before this.

At no tume did her condition give rise to any anxiety

Postoperatively the following were her cholinesterase estimations (Warburg) serum cholinesterase-120, red cell cholinesterase-96. The serum potassium was not estimated.

\section{Case 2}

C.P A young married girl age 23 years was presented for oesophagoscopy. Before operation nothing abnormal was found Premedication was morphia gr. $1 / 6$ and atropine gr. $1 / 100,1$ hour before.

She was induced with $500 \mathrm{mg}$ of Thopentone and $50 \mathrm{mg}$. of Scoline ${ }^{\circledR}$. Intubation was carried out and maintenance was nitrous oxide and oxygen 6/2 litres. The procedure took fifteen minutes to complete but she was still apnoeic at the end of this time.

Nikethamide 5 cc. was given and repeated a few minutes later. Again the impression was gained that she became even more flaccid than before.

Hyper- and hypoventlation were again tried without success Oxygen 100 per cent was given for some periods

In all the apnoea persisted for $2 \frac{1}{2}$ hours and again the onset of consciousness almost coincided with adequate tidal exchange. Respirations had gradually commenced about three-quarters of an hour before they became adequate for oxygenation.

The cholinesterase estimations were. serum-37, red cell-not lestmated

In contrast to these two cases the following is the history of a case in which it was expected that a prolonged recovery time would result from succinylcholine, but in fact did not occur.

\section{Case 3}

F L. A man 48 years of age suffering from acute liver fallure with gross ascites developed an acute abdomen It was at once realized that owing to the hepatic condition his serum cholnesterase should be low (13) In fact a blood sample before operation showed it to be 44 Accordingly it was decided to use Scolne ${ }^{\circledR}$ to try his sensitivity to the drug

Induction was with Thiopentone $200 \mathrm{mg}$ and Scolıne ${ }^{\circledR 2} \mathrm{mg}$ Spontaneous respirations commenced in five minutes and an intravenous infusion of 0.1 per cent Scolnne ${ }^{\circledR}$ was commenced. Mantenance was with nitrous oxude and oxygen $6 / 2$ litres. The operation lasted $1 / 2$ hour, during which time a gangrenous appendix was removed. In all $150 \mathrm{mg}$. of Scolıne ${ }^{\circledR}$ were used and spontaneous respirations were present at the end of the procedure

His postoperative cholnnesterase estimations were serum-44, red cells-106

\section{Discussion}

It would appear from the experience gained from the above cases that a low serum cholinesterase is not the only factor in patients who show a prolonged effect from succinylcholine The low value was present in cases 2 and 3 , but in 
one the response was normal and in the other abnormal. Case 1 showed an abnormal response with a normal level of serum cholinesterase.

Many factors have been blamed for the prolonged apnoea due to succinyl. choline, among them hyperventilation (14), an alteration of the patient's ph (10), persistent effect of thiopentone (8), overdosage (18) etc. Evans et al. (17) are quite definite that the low serum cholinesterase level is enough to explain the prolonged recovery time They, and Bourne, Somers ard Collier (16) between them have had eight cases of somewhat prolonged apnoeas and in each one the serum cholinesterase was low. Lehmann (13) goes so far as to state that "to produce dramatic delay in recovery the enzyme level must obviously be very low." Evans et al., however, had two further instances which they could not explain by low serum cholinesterase value. In these they suggested a low serum potassium as being a possible causal factor.

That a low serum cholinesterase level is a factor is undoubtedly true, but I am convinced that there must be others, which in the present state of our know]edge are not yet apparent

In my opinion it is quite possible that where the patient responds with an apnoea of abnormal duration, succinylcholne or its breakdown products may exert a central as well as a peripheral effect. I am prompted to this conclusion by the delay in the return to consciousness until the return of respirations, despite the administrations of 100 per cent oxygen. Others have reported similarly.

\section{Methods of Treatment}

Presuming that the delay in recovery is caused by a low level of serum cholinesterase, then the rational treatment is the raising of this level, either by intravenous injections of concentrated serum cholnesterase or by fresh blood transfusions Dramatic results have been claimed for the transfusions of fresh blood (5) (6), but this may not be readily available in many hospitals, and the apnoea may well have terminated by the time a supply becomes avallable.

Concentrated serum cholinesterase has shortened the period of paralysis (17), but has yet to be used in a case showing real sensitivity to succinylcholine.

Some authors have administered neostgmine (in pure desperation, I think), but since this is an anticholinesterase, it is not surprising that it was unsuccessful

Large doses of nikethamide (up to $20 \mathrm{cc}$.) have apparently been successful (8), but in these instances it may well have been the induction barbiturate that caused the apnoea. My distinct impression in both cases 1 and 2 was that nukethamide did more harm than good, and in case 1 it certainly abolished the tiny respiratory movements that were present

The following suggestions may prove helpful when a patient responds to succinylcholine with a prolonged apnoea.

1. Endeavour to control respiration without either hypo- or hyperventilation.

2 If an intravenous barbiturate has been given shortly before, administer picrotoxin.

3. Introduce a sudden strong concentration of ether vapour into the circuit. If 
this results in coughing or straming then the apnoea is not due to peripheral paralysis.

4 If the patient has had both a long-acting relaxant as well as succinylcholme, neostigmine should not be given. Should the prolonged action be due to succinylcholine it will be very greatly extended, and if the longer acting relaxant is to blame recovery can be expected within an hour, without neostigmine.

5. Nikethamide is of doubtful benefit in these cases and unless strong suspicions are entertained that the intravenous barbiturate or other central respiratory depressants are causing the condition, it is better that the drug be witheld.

Except for concentrated serum cholmesterase, there appears to be no other remedy in these cases, and as a low serum cholinesterase is not an invariable finding, it is doubtful if even this would be of help in true sensitivity to succinylcholine.

\section{SUMMARY}

Case histories of three patients have been given in an effort to show that a low serum cholinesterase is by no means an invariable finding where prolonged recovery to succinylcholine occurs.

A theory is given of a possible mechanism in these cases.

Practical suggestions on treatment are offered.

\section{RÉSUMÉ}

L'auteur présente le cas de deux patients qui, sous l'effet de la succinyl cholıne, ne se reveillèrent qu'après deux heures et demie Chez l'un, la cholınesterase du serum était normale; chez l'autre, elle étalt basse.

Par ailleurs, un trossième patient, chez qui la cholnestercse étart basse avant l'opération, ne montra aucune réponse anormale à la succinyl cholıne.

On préconise la théorie d'un effet central dépresseur surajouté aux effets pérıphérıques pour explıquer ces cas d'apnée prolongée due à la succinyl cholıne.

\section{REFERENCES}

1 Bovet, D, Bovet-Niti, F, Guarino, S, Longo, V G, and Marotta, M R C 1st. Sup Sanita 12. 106 (1949) Quoted in Biology Abst 2432763 (1950)

2 Bovet-Nitri, F 1st Sup Sanita 12138 (1949) Quoted in Biology Abstr 2432764 (1950)

3 Evans, F. T, Gray, P W S, Lemmann, H and Silk, E Sensitivity to Succinylcholine in relation to Serum Cholnnesterase Lancet 11229 (1952)

4 Foldes, F F, Vanderwort, R S, Shanor, S P The Fate of Succinylcholine in Man. Anaesthesiology 1611 (1955)

5 Cowan, C A. Nine Hours Apnoea following Succinylcholne: Anaesthesia 9 23 (1952)

6 Harrison, B. L, Seward, E H and Skinner, L C. Prolonged Scoline Apnoea Treated by Blood Transfusion Anaesthesia 7. 152 (1952)

7. Calvert, S., Lehmann, H, Silk, E and Slack, W R Prolonged Apnoea after Suramethonium Lancet 2354 (1954)

8 Barron, D W Scoline Apnoea Brit Med J 2833 (1952).

9. Love, S. H S Prolonged Apnoea following Scolne Anaesthesia 7113 (1952)

10. Kennedy, H J Prolonged Respiratory Paralysis after Succinylcholine. Brit Med J 1 866 (1952). 
11 Hewer, L C Prolonged Respiratory Paralysis after Succinylcholine Bnt Med J 1971 (1952)

12 TheslefF, S. and Von Dardelo, O Nord Med. 46 1045 (1951)

13 LehmanN, H Succinylcholine Lancet 2199 (1952).

14 Ruchards, $H$ and Youngman, H R The Ultra-Short-Actıng Relaxants Brit Med J. 1 1334 (1952).

15 Foldes, F. F. Prolonged Respiratory Paralysis after Succinylcholine Brit Med J 1. 1352 (1952).

16 Bourne, J G, Collier, IH O $\mid$ and Somers, G F Succinylcholine (Succinoylcholine) Muscle-Relaxant of Short Action Lancet 11225 (1952)

17 Evans, F T, Gray, P W S, Lemmann, H and Silk, E Effect of Pseudo-Cholinesterase Level on action of Succinylcholine Brit Med J 1136 (1953) 